\title{
$\$$ Research Square

\section{High Levels of anti-Leishmania IgG3 and Low CD4+ T Cells Count were Associated with Relapses in Visceral Leishmaniasis}

\author{
Renata Kuschnir \\ Fundação Oswaldo Cruz \\ Leonardo Pereira \\ Fundação Hospitalar do Estado de Minas Gerais \\ Maria Rita Dutra \\ Fundação Hospitalar do Estado de Minas Gerais \\ Ludmila de Paula \\ Fundação Hospitalar do Estado de Minas Gerais \\ Maria Luciana Silva-Freitas \\ Fundação Oswaldo Cruz
}

\section{Gabriela Correa-Castro}

Instituto Federal de Educação, Ciência e Tecnologia do Rio de Janeiro

\section{Simone Cruz Silva}

Instituto Nacional de Infectologia Evandro Chagas, INI, Fiocruz

\section{Glaucia Cota}

Instituto Rene Rachou, Fiocruz, MG

\section{Joanna Santos-Oliveira}

Instituto Federal de Educação, Ciência e Tecnologia do Rio de Janeiro

Alda Da-Cruz ( $\sim$ alda@ioc.fiocruz.br)

Fundação Oswaldo Cruz

\section{Research Article}

Keywords: visceral leishmaniasis, relapses, clinical follow-up, immune response

Posted Date: December 23rd, 2020

DOI: https://doi.org/10.21203/rs.3.rs-127021/v1

License: (ㅇ (1) This work is licensed under a Creative Commons Attribution 4.0 International License. Read Full License

Version of Record: A version of this preprint was published at BMC Infectious Diseases on April 20th, 2021. See the published version at https://doi.org/10.1186/s12879-021-06051-5. 


\section{Abstract}

Background: Visceral leishmaniasis $(\mathrm{VL})$ is severe and potentially fatal. Brazil is one of the countries with the greatest endemicity for the disease in the world. The reduction of $C D 4^{+} \mathrm{T}$ lymphocytes, $\mathrm{B}$ cells activation and high levels of inflammatory cytokines (IL-6/IL-8/TNF/IL-1ß), plasma LPS, soluble CD14, anti-Leishmania IgG3 and low leptin levels are involved in the immunopathogenesis of VL, most associated with severe VL. Despite relapses occurring in about $4-5 \%$ of patients with VL not associated with HIV infection, the factors underlying relapses are little known. Our aim was to identify clinical, laboratory and immunological parameters that may be associated with recurrences in VL.

Methods: Fifteen VL patients recruited from Hospital Eduardo de Menezes (BH-MG) were grouped into relapsing ( $R-V L$, $\mathrm{n}=5)$ and non-relapsing (NR-VL, $\mathrm{n}=10)$ and evaluated during active disease, immediately after treatment (post-treatment) and six months post-treatment $(6 \mathrm{mpt})$. Clinical and laboratory data obtained from medical records were correlated with $\mathrm{CD}^{+}$and $\mathrm{CD} 8^{+} \mathrm{T}$ cell counts and anti-Leishmania Igs and IL- 6 plasma levels and compared to those parameters of ten healthy controls.

Results: During the active phase of $\mathrm{VL}$, despite similarity in the clinical symptoms, the rates of thrombocytopenia, elevated transaminases (AST and ALT) and hyperbilirubinemia were higher in the NR-VL group compared to $\mathrm{R}-\mathrm{VL}(p<0.05)$, a profile reversed during the post-treatment phase. All patients had low CD $4^{+} T$ counts in active phase, however, NR-VL patients had a higher gain of this cell type than $\mathrm{R}-\mathrm{VL}$ in the post-treatment $(p<0.05)$. There was a significant reduction in IgG3 levels during the follow-up in the NR-VL group compared to the R-VL, especially at 6 mpt $(p<0.05)$. In addition, IgG3 levels were negatively correlated with CD $4^{+} T$ counts in the R-VL group ( $\left.r=-0.52\right)$. Elevated levels of IL- 6 were observed in active $\mathrm{VL}$ and correlated with clinical markers of severity.

Conclusions: During active phase of VL, the NR-VL patients presented more severe laboratorial abnormalities compared to $\mathrm{R}-\mathrm{VL}$, probably because the latter had already received previous treatment. On the other hand, $\mathrm{R}-\mathrm{VL}$ exhibited greater impairment of immune reconstitution and a high degree of B lymphocyte activation, which must be a factor that favored relapses.

\section{Background}

Visceral leishmaniasis (VL) is caused by Leishmania (L.) infantum in Brazil, being transmitted to mammals by Lutzomyia longipalpis sand fly [1]. VL is endemic in more than 90 countries or territories, however, in 2017, few countries as Brazil, Ethiopia, India, Kenya, South Sudan and Sudan have concentrated more than 90\% of the cases [2]. In the Americas, 3,562 new cases of VL were diagnosed in 2018 and Brazil was responsible for $97 \%$ of them [3]. Belo Horizonte, located in Minas Gerais state, is one of the Brazilian cities with the highest number of VL patients, with 2,378 reported cases from 2007 to 2019 [4].

Pathogen and host's immune system interaction leads to different clinical presentation, predisposing a high variety of outcomes, since asymptomatic disease to high severity and risk of death. Commonly, most patients affected by VL respond well to anti-Leishmania treatment and evolve to the remission. However, there are those who evolve to the severe form of VL, with a high lethality rate [5]. In addition, relapse is also observed in medical practice [6-7].

Clinical and laboratory markers such as age, bleeding, edema, jaundice, dyspnea, bacterial infection, HIV/AIDS coinfection, leukocyte count below 1500 cells $/ \mathrm{mm}^{3}$, thrombocytopenia below $50,000 \mathrm{cells} / \mathrm{mm}^{3}$ and renal failure have also been linked to VL severity [8-9]. Also, several soluble molecules, such as elevated levels of IL-2R, IL-13, IL-6, IL-8, IL-27, TNF, soluble CD14 (sCD14) [10-13], soluble CD163 (sCD163) [14] and specific anti-Leishmania immunoglobulins [1516], as well as low leptin levels [17] have already been associated with severity of VL. Interestingly, IL-6 levels were also associated with risk of death in VL [12].

Page $2 / 21$ 
Indeed, besides parasite specific immunosuppression, the exuberant inflammatory condition constitutes the key mechanism in the physiopathology of $L$. infantum infection. Similar to what is seen in sepsis, severe dengue and severe malaria, high degree of cell activation and high levels of cytokines are seen in the active VL $[12,18-20]$. These mechanisms contribute to the immune response impairment, which in turn have a negative impact on the effector capacity to control the parasite. Therefore, these features can influence the clinical evolution of VL patients, in terms of clinical cure status, severity/death and disease recurrences/relapses.

Relapses are characterized by the resurgence of signs and symptoms after an initial improvement of a disease manifestation [21]. It is considered a risk factor for death in VL, especially in HIV-co-infected patients [22-23]. Recently, our group demonstrated that the maintenance of high levels of cell activation, microbial translocation products, antiLeishmania IgG3 and a low CD4 ${ }^{+} \mathrm{T}$ cell reconstitution could be associated with VL relapse in VL/HIV coinfected patients [23]. Moreover, this low immune reconstitution has been related to a greater impairment of the thymic output among VL/HIV-relapsing patients [24]. The inability to reconstitute the effector response seems to exert a key role in the VL relapses.

In Brazil, the official frequency of relapses after VL treatment among non HIV-infected patients is underestimated, although the compulsory notification form has a specific field to inform this clinical presentation [25]. In the literature, the vast majority of studies are related to therapeutic failure reports [26]. There are few VL relapses reports and those which have it, present a great variability in the incidence of relapses according to the population and regions studied [27-30]. In a Spanish cohort, VL relapse rate was 12\% [27] while in Sudan, the clinical follow-up during an epidemic in Babar showed $5.7 \%$ of relapses, most of patients concentrated in few families [31]. A previous Brazilian study showed relapse in $2.3 \%$ of children diagnosed with VL between 2006 and 2011 [30]. Based on secondary data, an analysis of VL cases also in Brazil from 2001 to 2010 showed that relapses occurred in 3.1\% of patients not co-infected with HIV [29].

Factors underlying clinical relapses in VL alone have not been deeply addressed. Clinical characteristics as male gender, extreme of age and discreet reduction of splenomegaly were risk factors associated with relapses in Indian VL patients [32-33]. In Georgia, a pediatric cohort showed that children younger than one-year-old had a higher chance of relapse as the ones who were late diagnosed [34]. More recently, a Brazilian study showed that in addition to HIV infection, thrombocytopenia, lower limb edema and secondary pneumonia were factors independently associated with relapse [28].

VL relapsing patients should not achieve an effector immune response able to maintain the remission of the disease. Herein, we actively monitored patients with VL, followed from the active disease phase up to 12 months after treatment and confirmed the presence of two distinct groups: those with primary VL without relapse along 6 months (assumed as single/life episode) and those with two or more VL episodes/life, either with relapse identified at the cohort enrollment or during the follow-up period. Our aim was to identify possible differences in clinical and immunological parameters that could infer mechanisms involved in recurrence of VL. We evidenced that after therapy, both groups improved hematological and biochemical parameters and reduced IL-6 levels. In contrast, VL relapsing patients maintained increased lgG3 levels besides lower $\mathrm{CD}^{+} \mathrm{T}$ cell counts in comparison to non-relapsing $\mathrm{VL}$ patients. These results suggest that VL relapsing patients keep a B cellular activation status along with a deficient $\mathrm{T}$ cell compartment reconstitution.

\section{Methods}

\section{Casuistic and study design}

Fifteen VL patients were recruited for a prospective cohort study carried out in an infectious diseases referral hospital in Belo Horizonte, MG, Brazil (Hospital Eduardo de Menezes- Fundação Hospitalar do Estado de Minas Gerais/ HEMFHEMIG) from May 2018 to September 2019. The inclusion criteria in this cohort was presence of fever, cytopenia or splenomegaly, age over 18 years, independently of gender. Pregnant women and patients with HIV-infection were 
excluded. The leishmaniasis diagnosis was confirmed by direct research of amastigotes in bone marrow aspirate or presence of anti-Leishmania antibodies in serum. The patients were divided in two groups: those who had experienced only one VL episode throughout life (non-relapsing - NR) and those experiencing more than one VL episode, either previously or during the prospective follow-up (relapsing - R - group). Also, ten healthy subjects were included (HS, $n=10)$ were included as controls.

Cure was defined clinically by the disappearance of fever associated to recovery of cytopenia and splenomegaly involution, if present. Relapses were parasitologicaly confirmed by direct examination or culture in NNN medium in patients presenting resurgence of fever, worsening cytopenia or increased splenomegaly, compared to the previous condition, as defined by Cota et al in 2017 [21]. Patients with clinical symptoms and parasitological confirmation of active VL were included only after appropriate written informed consent was obtained. This study was approved by the Ethical Committees of Instituto Oswaldo Cruz - FIOCRUZ, HEM-FHEMIG and Instituto René Rachou - FIOCRUZ.

Patients were followed prospectively for six months and evaluated in three visits: active phase of the disease (before antiLeishmania treatment), after anti-Leishmania treatment, and six months after treatment (6mpt). Some participants were followed up to 12 months after treatment (12mpt). Patient's data were obtained from the medical records: 1) clinical signs and symptoms - fever, asthenia, hyporexia, weight loss, vomiting, diarrhea, bleeding, pallor, edema, splenomegaly, hepatomegaly, jaundice and underlying bacterial infection; 2) laboratory data - blood cell counts, biochemical tests related to liver and kidney function.

In each study visit, $45 \mathrm{~mL}$ of peripheral blood were collected from each patient, divided into 3 tubes with heparin (10 mL each) and 3 tubes with EDTA ( $5 \mathrm{~mL}$ each). The whole blood conserved in EDTA was used for the CD $4^{+} / \mathrm{CD}^{+} \mathrm{T}$ lymphocytes count, while the plasma in heparin tube was used to evaluate the anti-Leishmania IgG immunoglobulins levels and the IgG1 and IgG3 subclasses, as well as the levels of IL-6. The VL therapy was defined on individual basis according to the service routine and Brazilian Minister of Health recommendations [1].

\section{Absolute T-cell counts quantification}

Absolute T lymphocyte counts were determined using the BD Multitest monoclonal antibodies anti-CD45-PerCP, anti-CD3FITC, anti-CD4-APC, and anti-CD8-PE (BD ${ }^{\circledR}$ Biosciences, Franklin Lakes, NJ, USA) according to the manufacturer's instructions and as described previously by Silva-Freitas et al. (2016) [23]. The counts were acquired using a FACSCalibur and later the FACSVia. The data were analyzed with Multiset software (BD $\left.{ }^{\circledR}, \mathrm{USA}\right)$. The results are expressed as the number of cells per cubic millimeter (cells $/ \mathrm{mm}^{3}$ ) and was performed at the reference service of the Instituto Nacional de Infectologia Evandro Chagas, FIOCRUZ.

\section{Anti-Leishmania immunoglobulin assessment}

An ELISA was performed as previously described in Silva-Freitas et al. (2016) [23], with some modifications. Briefly, L. (L.) infantum (MHOM/BR/1974/PP75) soluble promastigote $(40 \mu \mathrm{g} / \mathrm{mL})$ was used to coat a polystyrene flat-bottom microtiter plate (Nunc-Immuno, Roskilde, Denmark). In this assay, plasma samples from VL patients were diluted as follows: $1: 10,000$ to $\lg G, 1: 2,000$ to $\lg G 1$ and $1: 200$ to $\lg G 3$. Then, diluted peroxidase-conjugated mouse monoclonal antihuman immunoglobulin G (IgG) (1:1000) (Invitrogen, San Francisco, CA, USA) and diluted monoclonal anti-human IgG1 (1:500) and IgG3 (1:400) (Zymed Laboratories Inc., San Francisco, CA, USA) were used. The absorbance was measured with a Benchmark microplate reader (Bio-Rad Laboratories, Hercules, CA, USA) at $492 \mathrm{~nm}$. The results were expressed as an ELISA index (EI), which is based on the division of the average optical density (OD) of the duplicates of the patient samples, by the average OD obtained from the negative controls. 


\section{Quantitation of IL-6 levels in plasma}

IL-6 levels were quantified in plasma samples stored at $-70^{\circ} \mathrm{C}$ using a commercial kit (IL-6 Quantikine ELISA, R\&D Systems, Minneapolis, Maryland, USA), according to the manufacturer's recommendations. A standard seven-point curve diluted in calibration reagent, as well as plasma samples were quantified in duplicate. The optical density was determined by the Microplate reader Benchmark equipment (Bio-Rad Laboratories, Hercules, CA, USA) at $450 \mathrm{~nm}$. The results were expressed in picograms per milliliter $(\mathrm{pg} / \mathrm{mL})$, and the minimum detection limit was $3.13 \mathrm{pg} / \mathrm{mL}$.

\section{Statistical analysis}

Laboratorial parameters were expressed in medians with interquartile ranges shown in square brackets. The gain of CD ${ }^{+}$ and $\mathrm{CD}^{+} \mathrm{T}$ lymphocytes was performed based on the ratio between the number of cells present at a given time and the number of cells present in the active phase of VL. Comparisons between the two groups of VL patients (NR and R) and between each VL group and the control group were performed using the unpaired and non-parametric, Mann Whitney ttest. Wilcoxon tests for paired variables with skewed distributions were also used for comparisons involving the same individual at different times. Spearman's test was used for correlation analysis. The statistical analyses were performed using SPSS ${ }^{\circledR}$ version 16 (multivariate analysis) and GraphPad Prism software (version 6.0, San Diego, CA, USA). Differences were considered statistically significant when the $p$ value was $<0.05$.

\section{Results}

\section{Clinical and laboratory characteristics of non-relapsing and relapsing visceral leishmaniasis patients in active phase and after anti- Leishmania treatment}

Fifteen VL patients were enrolled in the study (Table 1). During active VL phase, fever, asthenia and weight loss were reported by 14 (93\%), 11 (73\%) and 12 (80\%) patients, respectively. Splenomegaly was identified in all patients based on physical examination and/or imaging tests, and 12 patients had a concomitant liver enlargement. Considering the severity markers defined by the Brazilian Minister of Health, three patients complained of abdominal pain, two patients reported bleeding prior to hospitalization and one presented hematemesis during the clinical evolution. Ten patients received antibiotic therapy for suspected or confirmed concomitant bacterial infection.

Only one patient completed treatment using amphotericin B deoxycholate, whereas most patients required the use of amphotericin B lipid formulations (Table 1). R-VL patients showed higher accumulated dose during the treatment in active phase, although without significant difference between groups (Table 1 and 2). 
Table 1

Clinical characteristics of non-relapsing and relapsing VL patients

\begin{tabular}{|c|c|c|c|c|c|c|c|}
\hline Patient & Comorbidities & $\begin{array}{l}\text { Time } \\
\text { between } \\
\text { first } \\
\text { episode } \\
\text { and } \\
\text { actual } \\
\text { active } \\
\text { phase }\end{array}$ & $\begin{array}{l}\text { Total } \\
\text { number } \\
\text { of VL } \\
\text { episodes }\end{array}$ & $\begin{array}{l}\text { Relapse } \\
\text { during } \\
\text { follow- } \\
\text { up }\end{array}$ & $\begin{array}{l}\text { Active phase } \\
\text { treatment }\end{array}$ & $\begin{array}{l}\text { Cumulative } \\
\text { Amph B } \\
\text { dose } \\
\text { in VL } \\
\text { active } \\
\text { phase }\end{array}$ & $\begin{array}{l}\text { Total } \\
\text { follow-up }\end{array}$ \\
\hline VL01 & $\begin{array}{l}\text { Smoker } \\
\text { Previous marijuana use } \\
\text { Occasional use of } \\
\text { alcohol }\end{array}$ & NA & 1 & No & $\begin{array}{l}\text { Amph. B } \\
\text { deoxychol } \\
50 \mathrm{mg} / \text { day per } \\
12 \text { days } \\
\text { followed by } \\
\text { Liposomal } \\
\text { Amph. B } \\
20 \mathrm{mg} / \mathrm{kg}\end{array}$ & $28.5 \mathrm{mg} / \mathrm{kg}$ & $\begin{array}{l}12 \\
\text { months }\end{array}$ \\
\hline VL02 & No information & NA & 1 & No & $\begin{array}{l}\text { Liposomal } \\
\text { Amph. B } \\
20 \mathrm{mg} / \mathrm{kg}\end{array}$ & $20 \mathrm{mg} / \mathrm{kg}$ & $\begin{array}{l}12 \\
\text { months }\end{array}$ \\
\hline VL03 & $\begin{array}{l}\text { Occasional use of } \\
\text { alcohol } \\
\text { Positive serology for } \\
\text { Chagas Disease }\end{array}$ & NA & 1 & No & $\begin{array}{l}\text { Amph. B } \\
\text { deoxychol } \\
50 \mathrm{mg} / \text { day per } 3 \\
\text { days followed } \\
\text { by Liposomal } \\
\text { Amph. B } \\
20 \mathrm{mg} / \mathrm{kg}\end{array}$ & $21.7 \mathrm{mg} / \mathrm{kg}$ & $\begin{array}{l}12 \\
\text { months }\end{array}$ \\
\hline VL04 & $\begin{array}{l}\text { Virchowian hanseniasis } \\
\text { ADHD } \\
\text { Development delay - } \\
\text { infantilized behavior }\end{array}$ & NA & 1 & No & $\begin{array}{l}\text { Amph. B } \\
\text { deoxychol } \\
50 \mathrm{mg} / \text { day per } 4 \\
\text { days followed } \\
\text { by Liposomal } \\
\text { Amph. B } \\
20 \mathrm{mg} / \mathrm{kg}\end{array}$ & $22 \mathrm{mg} / \mathrm{kg}$ & $\begin{array}{l}12 \\
\text { months }\end{array}$ \\
\hline VL05 & $\begin{array}{l}\text { Dyslipidemia } \\
\text { Past of drug addiction }\end{array}$ & NA & 1 & No & $\begin{array}{l}\text { Amph. B } \\
\text { deoxychol - } \\
\text { 1000mg* }\end{array}$ & & $\begin{array}{l}\text { Post- } \\
\text { treatment }\end{array}$ \\
\hline VL06 & $\begin{array}{l}\text { Arterial hypertension } \\
\text { Diabetes mellitus type } \\
2 \\
\text { Metabolic syndrome }\end{array}$ & $\begin{array}{l}4 \\
\text { months }\end{array}$ & 2 & No & $\begin{array}{l}\text { Amph. B Lipid } \\
\text { Complex } \\
20 \mathrm{mg} / \mathrm{kg}\end{array}$ & $20 \mathrm{mg} / \mathrm{kg}$ & $\begin{array}{l}12 \\
\text { months }\end{array}$ \\
\hline VL07 & $\begin{array}{l}\text { Occasional use of } \\
\text { alcohol }\end{array}$ & $\begin{array}{l}15 \\
\text { months }\end{array}$ & 5 & $\begin{array}{l}\text { Yes } \\
\text { Jan, } \\
2019\end{array}$ & $\begin{array}{l}\text { Amph. B Lipid } \\
\text { Complex } \\
40 \mathrm{mg} / \mathrm{kg}\end{array}$ & $40 \mathrm{mg} / \mathrm{kg}$ & $\begin{array}{l}12 \\
\text { months }\end{array}$ \\
\hline VL08 & $\begin{array}{l}\text { Arterial hypertension } \\
\text { Smoker } \\
\text { Alcoholic }\end{array}$ & NA & 1 & No & $\begin{array}{l}\text { Amph. B Lipid } \\
\text { Complex } \\
20 \mathrm{mg} / \mathrm{kg}\end{array}$ & $20 \mathrm{mg} / \mathrm{kg}$ & $\begin{array}{l}12 \\
\text { months }\end{array}$ \\
\hline VL09 & $\begin{array}{l}\text { Chronic renal disease } \\
\text { Hypersplenim }\end{array}$ & $\begin{array}{l}15 \\
\text { months }\end{array}$ & 4 & $\begin{array}{l}\text { Yes } \\
\text { Oct, } \\
2019\end{array}$ & $\begin{array}{l}\text { Amph. B Lipid } \\
\text { Complex } \\
20 \mathrm{mg} / \mathrm{kg}\end{array}$ & $20 \mathrm{mg} / \mathrm{kg}$ & $\begin{array}{l}12 \\
\text { months }\end{array}$ \\
\hline
\end{tabular}




\begin{tabular}{|c|c|c|c|c|c|c|c|}
\hline \multirow[b]{2}{*}{ VL10 } & \multicolumn{7}{|l|}{$\begin{array}{l}\text { Past of } \\
\text { schistosomiasis }\end{array}$} \\
\hline & $\begin{array}{l}\text { Chagasic cardiac } \\
\text { insufficiency }\end{array}$ & 0 & 2 & $\begin{array}{l}\text { Yes } \\
\text { Feb, } \\
2019\end{array}$ & $\begin{array}{l}\text { Amph. B Lipid } \\
\text { Complex } \\
25 \mathrm{mg} / \mathrm{kg}\end{array}$ & $25 \mathrm{mg} / \mathrm{kg}$ & 6 months \\
\hline VL11 & $\begin{array}{l}\text { Alcoholic } \\
\text { Ex-smoker } \\
\text { Past of } \\
\text { schistosomiasis and } \\
\text { gonorrhea }\end{array}$ & NA & 1 & No & $\begin{array}{l}\text { Amph. B Lipid } \\
\text { Complex } \\
200 \mathrm{mg} / \text { day for } \\
4 \text { days followed } \\
\text { by Liposomal } \\
\text { Amph. B } \\
20 \mathrm{mg} / \mathrm{kg} \text { (in } 7 \\
\text { weeks) }\end{array}$ & $20 \mathrm{mg} / \mathrm{kg}$ & 6 months \\
\hline VL12 & Drug addicted & NA & 1 & No & $\begin{array}{l}\text { Amph. B } \\
\text { deoxychol } \\
\text { 150mg followed } \\
\text { by Liposomal } \\
\text { Amph. B } \\
20 \mathrm{mg} / \mathrm{kg}\end{array}$ & $23 \mathrm{mg} / \mathrm{kg}$ & 6 months \\
\hline VL13 & $\begin{array}{l}\text { Alcoholic } \\
\text { Smoker }\end{array}$ & NA & 1 & No & $\begin{array}{l}\text { Meglumine } \\
\text { antimoniate } 20 \\
\text { mgSb+5/Kg/day } \\
\text { for } 3 \text { days } \\
\text { followed by } \\
\text { Liposomal } \\
\text { Amph. B } \\
20 \mathrm{mg} / \mathrm{kg}\end{array}$ & $20 \mathrm{mg} / \mathrm{kg}$ & $\begin{array}{l}\text { Post- } \\
\text { treatment }\end{array}$ \\
\hline VL14 & $\begin{array}{l}\text { Arterial hypertension } \\
\text { Ex-smoker }\end{array}$ & NA & 1 & No & $\begin{array}{l}\text { Liposomal } \\
\text { Amph. B } \\
20 \mathrm{mg} / \mathrm{kg} \text { in7 } \\
\text { days }\end{array}$ & $20 \mathrm{mg} / \mathrm{kg}$ & $\begin{array}{l}\text { Post- } \\
\text { treatment }\end{array}$ \\
\hline VL15 & $\begin{array}{l}\text { Ex-smoker } \\
\text { Pulmonary } \\
\text { hypertension } \\
\text { Subclinic } \\
\text { hypothyroidism }\end{array}$ & $\begin{array}{l}5 \\
\text { months }\end{array}$ & 3 & No & $\begin{array}{l}\text { Liposomal } \\
\text { Amph. B } \\
40 \mathrm{mg} / \mathrm{kg}\end{array}$ & $40 \mathrm{mg} / \mathrm{kg}$ & $\begin{array}{l}\text { Post- } \\
\text { treatment }\end{array}$ \\
\hline
\end{tabular}


Table 2

Clinical and laboratory differences between relapsing and non-relapsing visceral leishmaniasis patients

\begin{tabular}{|c|c|c|c|}
\hline \multirow[t]{2}{*}{$\begin{array}{l}\text { Analyzed } \\
\text { parameters }\end{array}$} & \multicolumn{3}{|c|}{$\begin{array}{l}\text { Visceral leishmaniasis patients } \\
\text { [median (IQR)] }\end{array}$} \\
\hline & $N R(n=10)$ & $R(n=5)$ & $p$-value \\
\hline $\operatorname{Sex}(M / F)$ & $11 / 2$ & $4 / 1$ & NA \\
\hline \multirow[t]{2}{*}{ Age (years) } & 38 & 44 & 0.49 \\
\hline & $(30.8-46.5)$ & $(30-61)$ & \\
\hline \multirow[t]{2}{*}{ Total number of VL episodes (n) } & 1 & 3 & NA \\
\hline & & $(2-5)$ & \\
\hline \multirow[t]{2}{*}{ Acumulated dose of Amph. B in actual active phase $(\mathrm{mg} / \mathrm{kg})$} & 20 & 25 & 0.24 \\
\hline & $(20-22.5)$ & $(20-40)$ & \\
\hline \multirow[t]{2}{*}{ PCR $(\mathrm{mg} / \mathrm{dL})$} & 72 & 54.5 & 0.76 \\
\hline & $(42.3-154.5)$ & $(39.5-174.5)$ & \\
\hline \multirow[t]{2}{*}{ Platelet $\left(x 10^{3} \mathrm{cel} / \mathrm{mm}^{3}\right)$} & 68 & 107 & 0.01 \\
\hline & $(42.8-80.8)$ & $(88-216.5)$ & \\
\hline \multirow[t]{2}{*}{ AST (U/L) } & 69.5 & 38 & 0.03 \\
\hline & $(56.8-195.8)$ & $(24-79)$ & \\
\hline \multirow[t]{2}{*}{ Total bilirubin (mg/dL) } & 0.9 & 0.5 & 0.03 \\
\hline & $(0.7-1.0)$ & $(0.5-0.8)$ & \\
\hline
\end{tabular}

Regarding liver function, transaminases levels (AST and/or ALT) were augmented in the majority of NR-VL (7 out 10), but in only one out 5 of the R-VL group ( $p<0.05$, Table 2$)$. The total bilirubin was at normal levels in both groups; however, the direct bilirubin (DB) levels were more elevated in NR-VL (7 out 10) than in R-VL, in which only one patient presented a slight increase of DB (Table 2 and Supplementary Table 1). A high degree of inflammatory activity can be inferred from the elevation of C-reactive protein (NR-VL $=72 \mathrm{mg} / \mathrm{dL}[42.3-154.5 \mathrm{mg} / \mathrm{dL}]$ and $\mathrm{R}=54.5 \mathrm{mg} / \mathrm{dL}[39.5-174.5 \mathrm{mg} / \mathrm{dL}]$ ), compared to normal parameters $(<10 \mathrm{mg} / \mathrm{dL}$ ), with no statistical difference between groups of patients (Table 2 and Supplementary Table 1).

Considering hematological parameters, all patients had anemia, leukopenia and thrombocytopenia. NR-VL patients presented the lowest cell types counts compared to R-group, but only differences on platelets counts were statistically significative $(p<0.05)$ (Table 2 and Supplementary Table 1$)$. After treatment, NR-VL patients showed a significant increase in total leukocytes from $1,300 \mathrm{cells} / \mathrm{mm}^{3}\left[975-1,775 \mathrm{cells} / \mathrm{mm}^{3}\right]$ to $2,950 \mathrm{cells} / \mathrm{mm}^{3}\left[1,825-3,675 \mathrm{cells} / \mathrm{mm}^{3}\right]$. From these, lymphocytes, monocytes, and neutrophils significantly augmented after therapy $(p<0.05)$ (Figure 1$)$. This increase of leucocytes also occurred in R patients, but the differences were not significant (Figure 1). Finally, the NR-VL group also showed a significant increase in platelet counts immediately after treatment in relation to the active phase of VL.

\section{Visceral leishmaniasis relapses were associated with maintenance of low CD4 ${ }^{+}$T-cells}


All VL patients, regardless of being from R- or NR-VL group, had lower CD4 ${ }^{+}$T cell counts (NR-VL - 312.5 cells $/ \mathrm{mm}^{3}[205.8$ 509 cells $\left./ \mathrm{mm}^{3}\right]$ and $\left.\mathrm{R}-232 \mathrm{cell} / \mathrm{mm}^{3}\left[76.5-368.5 \mathrm{cell} / \mathrm{mm}^{3}\right]\right)$ during active VL compared to HS $\left(1,115 \mathrm{cell} / \mathrm{mm}^{3}[630.5-\right.$ $\left.1,258 \mathrm{cell} / \mathrm{mm}^{3}\right]$ ) (Figure $2 \mathrm{~A}$ ). However, immediately after treatment a significant increase of CD $4^{+} \mathrm{T}$-cell counts was observed in the NR-VL group, but not in R group. Likewise, the gain of CD4 ${ }^{+} \mathrm{T}$ lymphocytes after anti-Leishmania treatment was 1.69 times [1.41-2.05 times] in relation to the active phase of the disease $(p<0.05)$; while the gain in patients $\mathrm{R}$ was 0.99 [0.95-1.48] (Figure 2B).

After six months of treatment (6mpt), NR-VL patients still maintained higher CD $4^{+} \mathrm{T}$ lymphocyte counts than R patients (NR-VL - 906 cells/mm³ [664-1097 cells/mm³]; R-VL - 532 cells $/ \mathrm{mm}^{3}$ [131-532 cells/mm $\mathrm{mm}^{3}$ ) (Figures 2A and 2B). Some patients were followed up to $12 \mathrm{mpt}$ and among NR-VL, four patients presented CD4 ${ }^{+} \mathrm{T}$ counts above than $800 \mathrm{cells} / \mathrm{mm}^{3}$ $\left(1,074 \mathrm{cell} / \mathrm{mm}^{3}\left[731.5-1,226 \mathrm{cell} / \mathrm{mm}^{3}\right]\right.$ very similar to those found in HS $\left(1,115 \mathrm{cell} / \mathrm{mm}^{3}\left[630.5-1,258 \mathrm{cell}^{3} \mathrm{~mm}^{3}\right]\right)$ (Figures $2 \mathrm{~A}$ ). On the other hand, even at a long term post-therapy, R-VL patients still presented the lowest CD $4^{+} \mathrm{T}$ cell counts (734 cell/mm $\mathrm{mm}^{3}\left[76-1,438 \mathrm{cell} / \mathrm{mm}^{3}\right]$ ) (Figures $2 \mathrm{~A}$ and $\left.2 \mathrm{~B}\right)$.

Regarding $\mathrm{CD}^{+} \mathrm{T}$ lymphocytes, both NR-VL and R-VL patients showed lower numbers of this subpopulation than those found in HS (Figure $2 \mathrm{C}$ ) up to $6 \mathrm{mpt}$. At $12 \mathrm{mpt}$, the $\mathrm{CD} 8^{+}$T-cells reached counts very similar to those found in HS (Figures $2 \mathrm{C})$ in both groups.

Interestingly, the $\mathrm{CD}^{+} \mathrm{T}$-cell counts were positively correlated with the transaminase levels in the active phase of the disease: CD8 ${ }^{+}$T-cells and AST $(r=0.64 ; p<0.05)$ and with ALT $(r=0.63 ; p<0.05$ - Figure 2D and E).

\section{Relapsing visceral leishmaniasis patients maintain elevated IgG3 anti-Leishmania levels}

The IgG anti-Leishmania levels were measured by Elisa Index (EI). NR-VL patients presented lower levels of antiLeishmania IgG1 than R-VL group, independently of the clinical phase (active phase, post-treatment, six and 12mpt, Figure $3 A)$. It is interesting to note that NR-VL group has already presented a reduction in these levels soon after the antiLeishmania treatment, whereas higher antibodies levels persisted up to $6 \mathrm{mpt}$ in $\mathrm{R}$ patients (NR-VL = 20.2 [5.8-126.5]; R-VL $=75.4$ [42.8-105.3]) (Figure 3A). After $12 \mathrm{mpt}$, both groups had lower lgG1 levels, but the drop was more pronounced in RVL patients $(N R=12.5[3.8-43.8] ; R=5.6[1,6-20.5])$ (Figure $3 A)$.

In terms of IgG3 levels, NR-VL patients showed a reduction in these levels right after anti-Leishmania treatment in relation to the active phase of VL (active phase: 24.3 [11.2-36.6]; post-treatment: 17.8 [9, 6-35.14]). This reduction was more pronounced at six and $12 \mathrm{mpt}$ in NR-VL group. Besides, it is notable that such decrease was higher in NR-VL group when compared to $\mathrm{R}-\mathrm{VL}(\mathrm{p}<0.05)$, whose IgG3 levels remained elevated up to $6 \mathrm{mpt}$ (active phase: 33.1 [29.9-61.8]; posttreatment: 31.9 [22.2-60.9]; 6mpt: 27.3 [16.3-54.6]). Although R-VL patients showed a reduction in lgG3 titers after $12 \mathrm{mpt}$, these are still three times higher than those seen in NR-VL group at the same clinical phase $(\mathrm{NR}-\mathrm{VL}=3.6[2.7-12.2] ; \mathrm{R}-\mathrm{VL}=$ $12.0[0.25-90,5])$ (Figure 3B).

Finally, IgG3 anti-Leishmania levels correlated negatively with $\mathrm{CD} 4^{+} \mathrm{T}$ cell counts $(r=-0.52, p<0.05$, Figure $3 C)$ in $\mathrm{R}-\mathrm{VL}$ patients in all phases of the clinical follow-up, which reinforces that relapsing patients whose $C D 4^{+} T$ counts are lower are also those who have higher IgG3 levels.

\section{IL-6 levels correlated with laboratorial parameters of severity in visceral leishmaniasis patients}


In the active phase, IL-6 levels were above the minimum detection limit in 8 out $10 \mathrm{NR}-\mathrm{VL}$ and in 3 out $5 \mathrm{R}$-VL in relation to the HS, whose median was $0.1 \mathrm{pg} / \mathrm{mL}$ [0.1-165 pg/ml]. However, a reduction in these levels were observed immediately after the treatment in most patients of both groups (Figure 4A). For both VL groups, IL-6 levels were associated with several VL severity markers, during the active and post-treatment phases. A negative correlation was verified between IL- 6 levels and neutrophils $(r=-0.53, p<0.05$, Figure 4B), lymphocytes $(r=-0.52 ; p<0.05$, Figure $4 C)$, monocytes $(r=-0.48, p$ $<0.05$, Figure $4 \mathrm{D}$ ) and albumin ( $\mathrm{r}=-0.49 ; p<0.05$, Figure $4 \mathrm{E})$. On the other hand, IL-6 levels correlated positively with Creactive protein levels $(r=0.53 ; p<0.05)$ (Figure $4 \mathrm{~F})$.

\section{Discussion}

There are many studies carried out in India [33], Sudan [32], Georgia [34] and Brazil [28] addressing retrospectively nonHIV infected patients presenting a VL relapsing course, but divergent findings in terms of clinical and laboratorial aspects associated with relapses were found. In the present study, the patients' symptoms were quite similar in the active phase, and it was not possible to identify significant differences between R- and NR-VL groups. However, more intense laboratorial abnormalities were observed in NR-VL compared to R-VL group. As R-VL patients have previously undergone anti-Leishmania treatment, we believe that it may have contributed to a partial clinical recovery, with a reduction in the damage caused by the infection. However, this was not enough to restore the R-VL organic functions.

Splenomegaly at study enrollment was observed in both groups, being a usual manifestation of VL [9]. Splenomegaly and thrombocytopenia have already been identified as markers of VL relapses [28, 32-33]. NR-VL patients showed significant platelet elevation after treatment, different from observed for R-VL group. It is known that spleen histological disorganization affects its functionality [35] which implies in higher consumption of platelets, as a confounding factor, resulting in elevated parasitemia [9], and immunodepression related to its immunity function [32].

After VL treatment, a recovery of bone marrow cellularity was observed in NR-VL patients, especially with an increase in leukocytes levels compared to the active phase of VL. A significant and faster gain of CD4 ${ }^{+} \mathrm{T}$ cells was observed in $\mathrm{NR}-\mathrm{VL}$ patients immediately after anti-Leishmania treatment, but not in R-VL patients. Similar results were observed in VL/HIV coinfection [23]. This deficit in the recovery of $\mathrm{CD} 4^{+} \mathrm{T}$ lymphocytes can be related to an impaired input of cells originated from bone marrow, deficient replication rate or thymic dysfunction [24, 36-37]. Low CD4 ${ }^{+} \mathrm{T}$ cell counts in VL/HIV coinfected patients during the active phase of VL was a predictor of a poor prognosis: death or recurrence [38-39]. Thus, patients who are unable to restore the $\mathrm{CD} 4^{+} \mathrm{T}$ counts may be prone to relapse.

Interestingly, in the current series, all VL patients maintained low $\mathrm{CD}^{+} \mathrm{T}$ lymphocyte counts up to six months of follow-up, in relapsing and not relapsing groups. Whether $\mathrm{CD}^{+} \mathrm{T}$ cells contribute to protection, immunopathogenesis or even to the immunosuppression in VL is still unclear. Likewise, the function of these cells has already been described for human cutaneous leishmaniasis during the active and healing phases [40-43]. Some studies have showed that CD8 ${ }^{+} \mathrm{T}$ lymphocyte cytotoxic activity, secretion of cytokines and chemokines, granzyme B levels and lymphoproliferation may contribute to the parasite control in experimental and human VL [44-47]. At the same time, there was a positive correlation between the $\mathrm{CD} 8^{+} \mathrm{T}$ lymphocytes and transaminases levels. This raises the hypothesis that liver damage could be associated with cytotoxic activity. Such an association has already been demonstrated in hepatitis B [48] and in infectious mononucleosis by Epstein-Barr virus [49].

Also, endogenous IL-10 secretion has already been ascribed to the CD8 ${ }^{+} \mathrm{T}$ cells in VL which may contribute to the immunosuppression. Simultaneously, the chronic immune activation may lead $\mathrm{CD}^{+} \mathrm{T}$ lymphocytes to express molecules with inhibitory function on their surface, such as PD-1, CTLA-4 [50-51], TIM-3 and LAG3 [16]. In these situations of exhaustion of the cellular response, $\mathrm{CD} 8^{+} \mathrm{T}$ lymphocytes function may be severely impaired in active phase of VL [52]. 
In parallel, the levels of specific anti-Leishmania IgG and their subclasses after active VL may have an important role as marker of cure and/or predisposition to relapse $[17,53]$. Here, IgG3 levels are persistently increased in R-VL group in relation to NR-VL, which may show the presence of continuous parasite stimulation, without a complete control by the immune system. L. donovani Indian relapsing patients [54-55] have shown similar behavior for $\operatorname{lgG} 1$, whose levels remained high after the active episode of VL. In other studies [56-58], a reduction in IgG1 and IgG3 levels was found in patients infected either by L. infantum or by L. donovani, who were considered clinically cured few months after the treatment. In addition, we have found that a negative association between IgG3 and CD4+ T-cell count in R-VL patients, corroborating the link between persistence of high levels of IgG3 and relapse.

Finally, we observed that IL-6, a cytokine known to be inflammatory and already associated with a more severe prognosis in the evolution of VL $[12,17]$, was correlated to laboratory severity markers, such as hypoalbuminemia, leukopenia and thrombocytopenia. As expected, C-reactive protein (CRP) levels also correlated positively with IL- 6 since its binding with its receptor activates immunocompetent and hematological cells leading to the production of acute phase responses, as CRP [59]. However, there were patients that despite presenting clinical signs and laboratorial data associated with severity did not present elevated IL-6 levels, showing that other mechanisms in VL can trigger immunopathological mechanisms related to severity. This study design and the analysis performed until now are not sufficient to state the role of IL-6 may in the VL relapsing course. This study has limitations, including the small sample, the short follow-up time and mainly the comparison between patients enrolled at the primary but also at a relapsing VL episode, which can add differences in the total time of infection and in previous exposure to anti-Leishmania treatments. However, our results are hypothesis generator and rise important questions to be evaluated in a prospective study, as the potential of CD $4^{+}$T-cell count or IgG3 as biomarkers for VL relapses.

\section{Conclusion}

Therefore, the VL relapsing course among patients not infected with HIV and without recognized immunosuppression is a challenging reality considering the lack of understanding of the pathophysiological mechanisms involved, of reliable prognostic markers and clinical protocols for addressing the condition. Our findings suggest a deficit in T-cell reconstitution and maintenance of B-cell compartment activation as possible immunomechanisms underlying the $\mathrm{VL}$ relapse.

\section{Abbreviations}

$6 \mathrm{mpt}$ : six months post-treatment; $12 \mathrm{mpt}$ : twelve months after treatment; ADHD: attention deficit hyperactivity disorder; ALT: alanine aminotransferase; Amph. B deoxychol: Amphotericin B deoxycholate; Amph. B Lipid Complex: Amphotericin B lipid complex; AST: aspartate aminotransferase; CRP: C-reactive protein; DB: direct bilirubin; El: Elisa Index; F: female; HS: healthy subjects; IQR: interquartile range; Liposomal Amph. B: Liposomal amphotericin B; LPS: lipopolysaccharide; M: male; NA: not applicable; NR-VL: non-relapsing patients; OD: optical density; Post-treatment: right after treatment; R-VL: relapsing patients; sCD14: soluble CD14; SCD163: soluble CD163; Scr: serum creatinine; VL: Visceral leishmaniasis; yo: years old;

\section{Declarations}

\section{Ethics approval and consent to participate}

This study has been reviewed and approved by the Ethics Committee of Hospital Eduardo de Menezes (number 68118117.3.3002.5124), Instituto Rene Rachou (number 68118117.3.3001.5091) and Instituto Oswaldo Cruz - Fundação Oswaldo Cruz (number 68118117.3.1001.5248). The patients/participants provided their written informed consent to

Page $11 / 21$ 
participate in this study. We also confirm that all methods were performed in accordance with the relevant guidelines and regulations.

\section{Consent for publication}

Not applicable

\section{Availability of data and materials}

All data generated and/or analysed during this study are included in this published article [and its supplementary information files].

The datasets generated and/or analysed during the current study are not publicly available due individual privacy of patients could be compromised but are available from the corresponding author on reasonable request.

\section{Competing interests}

The authors declare that they have no competing interests.

\section{Funding}

This work was supported by the Instituto Oswaldo Cruz (internal funds: PAEF II-IOC-23-FIO-18-2-53), CNPq (Universal 433637/2018-8), FAPERJ (E-26/202.944/2016) and IFRJ (Pro-Ciência/2019). MLS-F received a fellowship from CAPES. GC-C received a fellowship from FAPERJ. AMD-C receive research fellowships from CNPq and FAPERJ. GC is currently receiving a grant from CNPq [301384/2019].

\section{Authors' contributions}

RCK, MLS-F, GC-C, JRS-O and AMD-C: formal analysis, investigation, methodology, organized the database, and wrote the draft of the manuscript.

JRS-O and AMD-C: conceptualization, funding acquisition, project administration, review and editing of the manuscript. GC: formal analysis and critically revised the manuscript for intellectual content.

LP, LSP, MRTD: recruitment and clinical follow-up of the patients.

SCCS: methodology and critically revised the manuscript for intellectual content.

All authors read and approved the final manuscript.

\section{Acknowledgements}

We would like to thank all the Eduardo de Menezes hospital staff who helped with the logistics of collecting and sending of the samples. We also acknowledge the participation of all the patients and healthy individuals enrolled in this study. 


\section{References}

1. Ministério da Saúde (BR), Secretaria de Vigilância em Saúde. Guia de vigilância em saúde. 2nd ed. Brasília; 2017. Available at: https://portalarquivos2.saude.gov.br/images/PDF/2017/outubro/16/Volume-Unico-2017.pdf. Accessed Dec 2019

2. World Health Organization. Leishmaniasis. 2018. Available at: https://www.who.int/leishmaniasis. Accessed Dec 2019.

3. Pan American Health Organization, World Health Organization. Leishmaniasis. Epidemiological report of the Americas. Washington: 2019. Available at: www.paho.org/leishmaniasis. Accessed Dec 2019.

4. Ministério da Saúde (BR). Sistema de Informação de Agravos de Notificação - Banco de dados do Sistema Único de Saúde - DATASUS. Available at: http://tabnet.datasus.gov.br/cgi/deftohtm.exe?sinannet/cnv/leishvmg.def. Accessed Sept 2020

5. Saporito L, Giammanco GM, De Grazia S, Colomba C. Visceral leishmaniasis: host-parasite interactions and clinical presentation in the immunocompetent and in the immunocompromised host. Int J Infect Dis. 2013; 17(8):e572-6 doi: 10.1016/j.ijid.2012.12.024.

6. Rodrigues da Silva J. Leishmaniose visceral (calazar). Rio de Janeiro. Tese [Concurso para provimento efetivo do cargo de professor catedrático da cadeira de Clinica das Doenças Tropicais e Infectuosas da Faculdade Nacional de Medicina da Universidade do Brasil]. Sociedade Editora e Gráfica Ltda; 1957.

7. Rossi M, Fasel N. How to master the host immune system? Leishmania parasites have the solutions! Int Immunol. 2017; doi: 10.1093/intimm/dxx075.

8. Sampaio MJAQ, Cavalcanti NV, Alves JGB, Fernandes Filho MJC, Correia JB. Risk Factors for Death in Children with Visceral Leishmaniasis. PLoS Negl Trop Dis. 2010; doi: 10.1371/journal.pntd.0000877.

9. Costa DL, Rocha RL, Chaves EBF, Batista VGV, Costa HL, Costa CHN. Predicting death from kala-azar: construction, development, and validation of a score set and accompanying software. Rev Soc Bras Med Trop. 2016; doi: 10.1590/0037-8682-0258-2016.

10. Barral-Netto M, Badaró R, Barral A, Almeida RP, Santos SB, Badaró F et al. Tumor Necrosis Factor (Cachectin) in Human Visceral Leishmaniasis. J Infect Dis. 1991; doi: 10.1093/infdis/163.4.853.

11. Santos-Oliveira JR, Regis EG, Leal CRB, Cunha RV, Bozza PT, Da-Cruz AM. Evidence that lipopolysaccharide may contribute to the cytokine storm and cellular activation in patients with visceral leishmaniasis. PLoS Negl Trop Dis. 2011; 5(7):e1198. doi: 10.1371/journal.pntd.0001198.

12. Costa DL, Rocha RL, Carvalho RMA, Lima-Neto AS, Harhay MO, Costa CHN, et al. Serum cytokines associated with severity and complications of kala-azar. Pathog Glob Health. 2013; 107(2):78-87. doi: $10.1179 / 2047773213 Y .0000000078$.

13. Santos PL, de Oliveira FA, Santos MLB, Cunha LCS, Lino MTB, dOliveira MFS, et al. The Severity of Visceral Leishmaniasis Correlates with Elevated Levels of Serum IL-6, IL-27 and SCD14. PLoS Negl Trop Dis. 2016; 10(1):e0004375. doi: 10.1371/journal.pntd.0004375.

14. Silva RLL, Santos MB, Almeida PLS, Barros TS, Magalhães L, Cazzaniga RA, et al. SCD163 levels as a biomarker of disease severity in leprosy and visceral leishmaniasis. PLoS Negl Trop Dis. 2017; 11(3):e0005486. doi: 10.1371/journal.pntd.0005486.

15. Ansari NA, Kumar R, Raj A, Salotra P. Elevated levels of IgG3 and IgG4 subclass in paediatric cases of kala azar. Parasite Immunol. 2008; 30(8):403-9. doi: 10.1111/j.1365-3024.2008.01036.x.

16. Singh B, Bhushan Chauhan S, Kumar R, Singh SS, Ng S, Amante F, et al. A molecular signature for CD ${ }^{+}$T cells from visceral leishmaniasis patients. Parasite Immunol. 2019; 41(11):e12669. doi: 10.1111/pim.12669. 
17. Fievez AMdC, Silva-Freitas ML, Sousa AdQ, Santos-Oliveira JR, Da-Cruz AM. Lower levels of leptin are associated with severity parameters in visceral leishmaniasis patients. PLoS One. 2019; 14(3):e0214413. doi: 10.1371/journal.pone.0214413.

18. Bozza FA, Cruz OG, Zagne SMO, Azeredo EL, Nogueira RMR, Assis EF, et al. Multiplex cytokine profile from dengue patients: MIP-1 beta and IFN-gamma as predictive factors for severity. BMC Infect Dis. 2008; 8:86. doi: 10.1186/1471-2334-8-86.

19. Andrade BB, Reis-Filho A, Souza-Neto SM, Clarêncio J, Camargo LMA, Barral A, et al. Severe Plasmodium vivax malaria exhibits marked inflammatory imbalance. Malar J. 2010; 9:13. doi: 10.1186/1475-2875-9-13.

20. Costa CHN, Werneck GL, Costa DL, Holanda TA, Aguiar GB, Carvalho AS, et al. Is severe visceral leishmaniasis a systemic inflammatory response syndrome? A case control study. Rev Soc Bras Med Trop. 2010; 43(4):386-92. doi: 10.1590/s0037-86822010000400010.

21. Cota GF, Sousa MR, Assis TSM, Pinto BF, Rabello A. Exploring prognosis in chronic relapsing visceral leishmaniasis among HIV infected patients: Circulating Leishmania DNA. Acta Trop. 2017; 172:186-191. doi: 10.1016/j.actatropica.2017.05.011.

22. Cota GF, Sousa MR, Mendonça ALP, Patrocinio A, Assuncao LS, de Faria SR, et al. Leishmania-HIV co-infection: clinical presentation and outcomes in an Urban Area in Brazil. PLoS Negl Trop Dis. 2014; 8(4):e2816. doi: 10.1371/journal.pntd.0002816.

23. Silva-Freitas ML, Cota GF, Machado-de-Assis TS, Giacoia-Gripp C, Rabello A, Da-Cruz AM et al. Immune Activation and Bacterial Translocation: A Link between Impaired Immune Recovery and Frequent Visceral Leishmaniasis Relapses in HIV-Infected Patients. PLoS ONE. 2016; 11(12):e0167512. doi: 10.1371/journal.pone.0167512.

24. Silva-Freitas ML, Corrêa-Castro G, Cota GF, Giacoia-Gripp C, Rabello A, Dutra JT, et al. Impaired Thymic Output Can Be Related to the Low Immune Reconstitution and T Cell Repertoire Disturbances in Relapsing Visceral Leishmaniasis Associated HIV/AIDS Patients. Front. Immunol. 2020; 11:953. doi: 10.3389/fimmu.2020.00953.

25. Ministério da Saúde (BR). Sistema de Informação de Agravos de Notificação Available at: http://portalsinan.saude.gov.br/leishmaniose-visceral/57-doencas-e-agravos. Accessed Sept 2019.

26. Gebreyohannes EA, Bhagvathula AS, Abegaz TM, Seid MA. Treatment outcomes of visceral leishmaniasis in Ethiopia from 2001 to 2017: a systematic review and meta-analysis. Infect Dis Poverty.2018; 7(1):108. doi: 10.1186/s40249018-0491-7.

27. Horrillo L, Castro A, Matía B, Molina L, García-Martínez J, Jaqueti J, et al. Clinical aspects of visceral leishmaniasis caused by $L$. infantum in adults. Ten years of experience of the largest outbreak in Europe: what have we learned? Parasit Vectors. 2019; 12(1):359. doi: 10.1186/s13071-019-3628-z.

28. Simão JC, Victória C, Fortaleza CMCB. Predictors of relapse of visceral leishmaniasis in inner São Paulo State, Brazil. Int J Infect Dis. 2020; 95:44-49. doi: 10.1016/j.ijid.2020.02.028

29. Gomes MLS. Coinfecção leishmaniose visceral e Aids no Brasil, 2001 a 2010. Rio de Janeiro. Dissertação [Mestrado em Epidemiologia e Saúde Pública] - Escola Nacional de Saúde Pública Sergio Arouca; 2012.

30. Caldas AJM, Lisbôa LLC, Silva PF, Coutinho NPS, SilvaTC. Perfil das crianças com leishmaniose visceral que evoluíram para óbito, falha terapêutica e recidiva em hospital de São Luís, Maranhão. Rev Pesq Saúde. 2013; 14(2): 91-95.

31. Marquet S, Bucheton B, Reymond C, Argiro L, EL-Safi SH, Kheir MM, et al. Exome Sequencing Identifies Two Variants of the Alkylglycerol Monooxygenase Gene as a Cause of Relapses in Visceral Leishmaniasis in Children, in Sudan. J Infect Dis. 2017; 216(1):22-28. doi: 10.1093/infdis/jix277.

32. Gorski S, Collin SM, Ritmeijer K, Keus K, Gatluak F, Mueller M, et al. Visceral leishmaniasis relapse in Southern Sudan (1999-2007): a retrospective study of risk factors and trends. PLoS Negl Trop Dis. 2010; 4(6):e705. doi: 10.1371/journal.pntd.0000705.

Page $14 / 21$ 
33. Burza S, Sinha PK, Mahajan R, Lima MA, Mitra G, Verma N, et al. Risk Factors for Visceral Leishmaniasis Relapse in Immunocompetent Patients following Treatment with $20 \mathrm{mg} / \mathrm{kg}$ Liposomal Amphotericin B (Ambisome) in Bihar, India. PLoS Negl Trop Dis. 2014; 8(1):e2536. doi: 10.1371/journal.pntd.0002536.

34. Kajaia M, Morse DL, Kamkamidze G, Butsashvili M, Chubabria G, Zenaishvili $O$ et al. Risk factors for relapse of visceral leishmaniasis in Georgia. Trop Med Int Health. 2011; 16(2):186-92. doi: 10.1111/j.1365-3156.2010.02694.x.

35. Hermida MD, de Melo CVB, Lima IDS, Oliveira GGS, dos-Santos WLC Histological Disorganization of Spleen Compartments and Severe Visceral Leishmaniasis. Front Cell Infect Microbiol. 2018; 8:394. doi: 10.3389/fcimb.2018.00394.

36. Carvalho EM, Bacellar O, Brownell C, Regis T, Coffman RL, Reed SG. Restoration of IFN-gamma production and lymphocyte proliferation in visceral leishmaniasis. J. Immunol. 1994; 152(12), 5949-5956.

37. da Silva AVA, Souza TL, Figueiredo FB, Mendes-Jr AAV, Ferreira LC, Filgueira CPB et al. Detection of amastigotes and histopathological alterations in the thymus of Leishmania infantum-infected dogs. Immun Inflamm Dis. 2020; 8(2):127-139. doi: 10.1002/iid3.285.

38. Cota GF, Sousa MR, Rabello A. Predictors of Visceral Leishmaniasis Relapse in HIV-Infected Patients: A Systematic Review. PLoS Negl Trop Dis. 2011; 5(6):e1153. doi: 10.1371/journal.pntd.0001153.

39. Távora LGF, Nogueira MB, Gomes ST. Visceral Leishmaniasis/HIV co-infection in northeast Brazil: evaluation of outcome. Braz J Infect Dis. 2015; 19(6):651-6. doi: 10.1016/j.bjid.2015.07.004.

40. Da-Cruz AM, Conceição-Silva F, Bertho AL, Coutinho SG. Leishmania-reactive CD4+ and CD8+ T cells associated with cure of human cutaneous leishmaniasis. Infect Immun. 1994; 62(6):2614-8. doi: 10.1128/IAI.62.6.2614-2618.1994.

41. Brodskyn Cl, Barral A, Boaventura V, Carvalho E, Barral-Netto M.

Parasite-driven in vitro human lymphocyte cytotoxicity against autologous infected macrophages from mucosal leishmaniasis. J Immunol. 1997; 159(9):4467-73.

42. Novais FO, Carvalho LP, Graff JW, Beiting DP, Ruthel G, Roos DS, et al. Cytotoxic T cells mediate pathology and metastasis in cutaneous leishmaniasis. PLoS Pathog. 2013; 9(7):e1003504. doi: 10.1371/journal.ppat.1003504.

43. Novais FO, Carvalho AM, Clark ML, Carvalho LP, Beiting DP, Brodsky IE, et al. CD8+ T cell cytotoxicity mediates pathology in the skin by inflammasome activation and IL-1 $\beta$ production. PLoS Pathog. 2017; 13(2):e1006196. doi: 10.1371/journal.ppat.1006196.

44. Mary C, Auriault V, Faugére B, Dessein AJ. Control of Leishmania infantum Infection Is Associated with CD81 and Gamma Interferon- and Interleukin-5-Producing CD41 Antigen-Specific T Cells. Infect Immun. 1999; 67(11):5559-66. doi: 10.1128/IAl.67.11.5559-5566.1999.

45. Tsagozis P, Karagouni E, Dotsika E. CD8(+) T cells with parasite-specific cytotoxic activity and a Tc1 profile of cytokine and chemokine secretion develop in experimental visceral leishmaniasis. Parasite Immunol. 2003; 25(1112):569-79. doi: 10.1111/j.0141-9838.2004.00672.x

46. Tsagozis P, Karagouni E, Dotsika E. Function of CD8+ T lymphocytes in a selfcuring mouse model of visceral leishmaniasis. Parasitol Int. 2005; 54(2):139-46. doi: 10.1016/j.parint.2005.02.005

47. Kaushal H, Bras-Gonçalves R, Negi NS, Lemesre JL, Papierok G, Salotra P. Role of CD8+ T cells in protection against Leishmania donovani infection in healed Visceral Leishmaniasis individuals. BMC Infect Dis. 2014; 14:653. doi: 10.1186/s12879-014-0653-6.

48. Lopes TGSL, Schinoni MI. Aspectos gerais da hepatite B. R. Ci. med. biol. 2011; 10(3):337-344.

49. Carvalho LH. Mononucleose infecciosa [Infectious mononucleosis]. J Pediatr (Rio J) 1999;75 Suppl 1:S115-25.

50. Day CL, Kaufmann DE, Kiepiela P, Brown JA, Moodley ES, Reddy S, et al. PD-1 expression on HIV-specific T cells is associated with T-cell exhaustion and disease progression. Nature. 2006; 443(7109):350-4. doi: $10.1038 /$ nature05115.

Page 15/21 
51. Kaufmann DE, Kavanagh DG, Pereyra F, Zaunders JJ, Mackey EW, Miura T, et al. Upregulation of CTLA-4 by HIVspecific CD4+ T cells correlates with disease progression and defines a reversible immune dysfunction. Nat Immunol. 2007; 8(11):1246-54. doi: 10.1038/ni1515.

52. Gautam S, Kumar R, Singh N, Singh AK, Rai M, Sacks D, et al. CD8 T cell exhaustion in human visceral leishmaniasis. J Infect Dis. 2014; 209(2):290-9. doi: 10.1093/infdis/jit401.

53. Marlais T, Bhattacharyya T, Singh OP, Mertens P, Gilleman Q, Thunissen C, et al. Visceral Leishmaniasis IgG1 Rapid Monitoring of Cure vs. Relapse, and Potential for Diagnosis of Post Kala-Azar Dermal Leishmaniasis. Front Cell Infect Microbiol. 2018; 8:427. doi: 10.3389/fcimb.2018.00427.

54. Bhattacharyya T, Ayandeh A, Falconar AK, Sundar S, El-Safi S, Gripenberg MA, et al. IgG1 as a Potential Biomarker of Post-chemotherapeutic Relapse in Visceral Leishmaniasis and Adaptation to a Rapid Diagnostic Test. PLoS Negl Trop Dis. 2014; 8(10):e3273. doi: 10.1371/journal.pntd.0003273.

55. Mollett G, Hinckel BCB, Bhattacharyya T, Marlais T, Singh OP, Mertens P, et al. Detection of Immunoglobulin G1 Against rK39 Improves Monitoring of Treatment Outcomes in Visceral Leishmaniasis. Clin Infect Dis. 2019; 69(7):1130-1135. doi: 10.1093/cid/ciy1062.

56. Ravindran R, Anam K, Bairagi BC, Saha B, Pramanik N, Guha SK, et al. Characterization of Immunoglobulin G and Its Subclass Response to Indian Kala-Azar Infection before and after Chemotherapy. Infect Immun. 2004; 72(2):863-70. doi: 10.1128/iai.72.2.863-870.2004.

57. Ganguly S, Das NK, Panja M, Pal S, Modak D, Rahaman M, et al. Increased levels of interleukin-10 and lgG3 are hallmarks of Indian post-kala-azar dermal leishmaniasis. J Infect Dis. 2008; 197(12):1762-71. doi: 10.1086/588387.

58. Gomes IT, Carvalho SFG, Rocha RDR, Peruhype-Magalhaes V, Dietze R, Martins-Filho OA, et al. Anti-Leishmania chagasi immunoglobulin G3 detected by flow cytometry for early cure assessment in American visceral leishmaniasis. J Immunol Methods. 2010; 360(1-2):76-83. doi: 10.1016/j.jim.2010.06.011.

59. Tanaka T, Narazaki M, Masuda K, Kishimoto T. Regulation of IL-6 in Immunity and Diseases. Adv Exp Med Biol. 2016; 941:79-88. doi: 10.1007/978-94-024-0921-5_4.

\section{Figures}




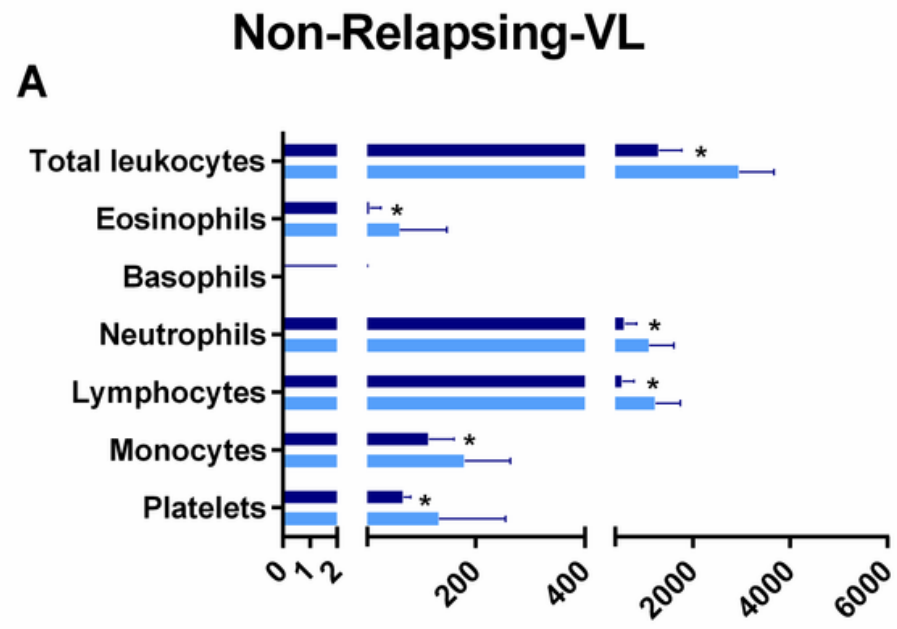

Cells $/ \mathrm{mm}^{3}$
B

\section{Relapsing-VL}

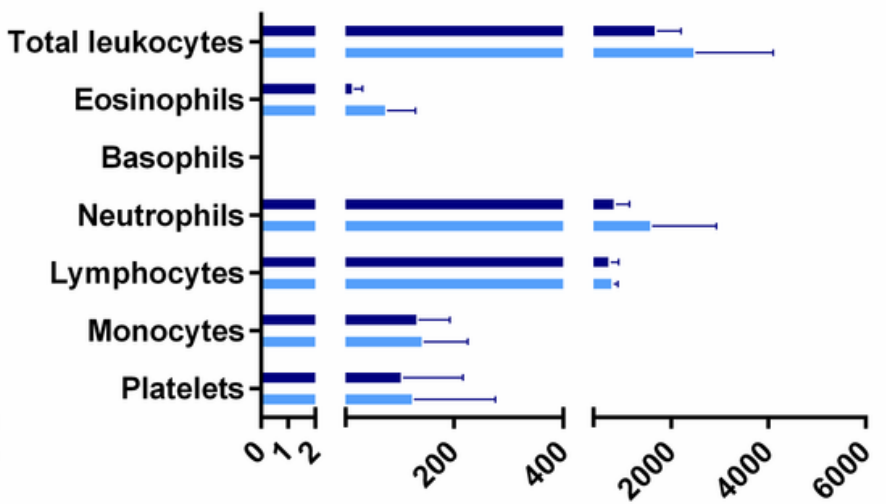

Cells $/ \mathrm{mm}^{3}$
C

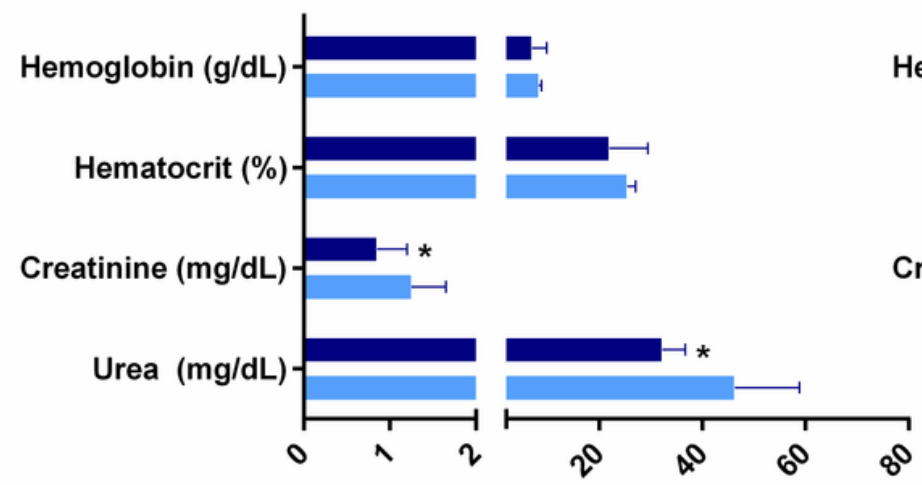

D

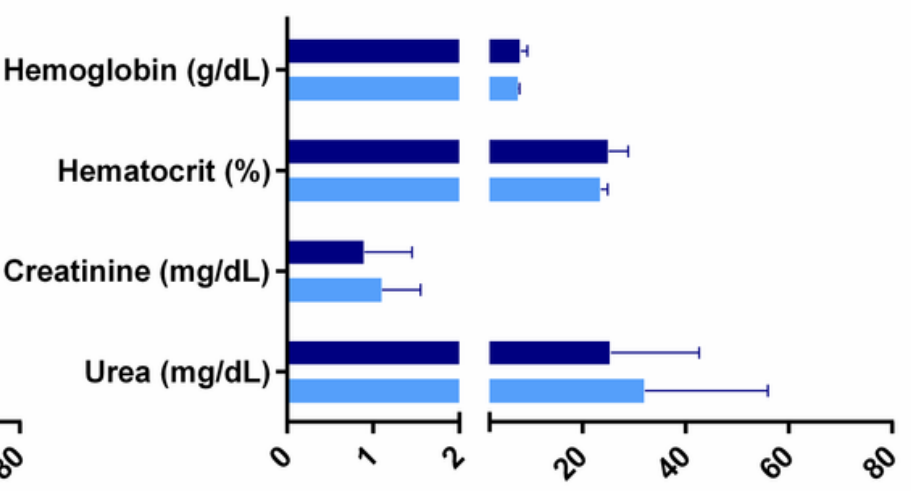

Post-treatment

Figure 1

Laboratorial indices of non-relapsing (NR-) and relapsing ( $R-$-) visceral leishmaniasis (VL) patients. Comparison between the median values of active phase and early post-treatment of NR ( $A$ and $C$ ) and R (B and $D)$ VL patients. Asterisks denote statistically significant differences between the phases of clinical follow-up: ${ }^{\star} p<0.05$. 

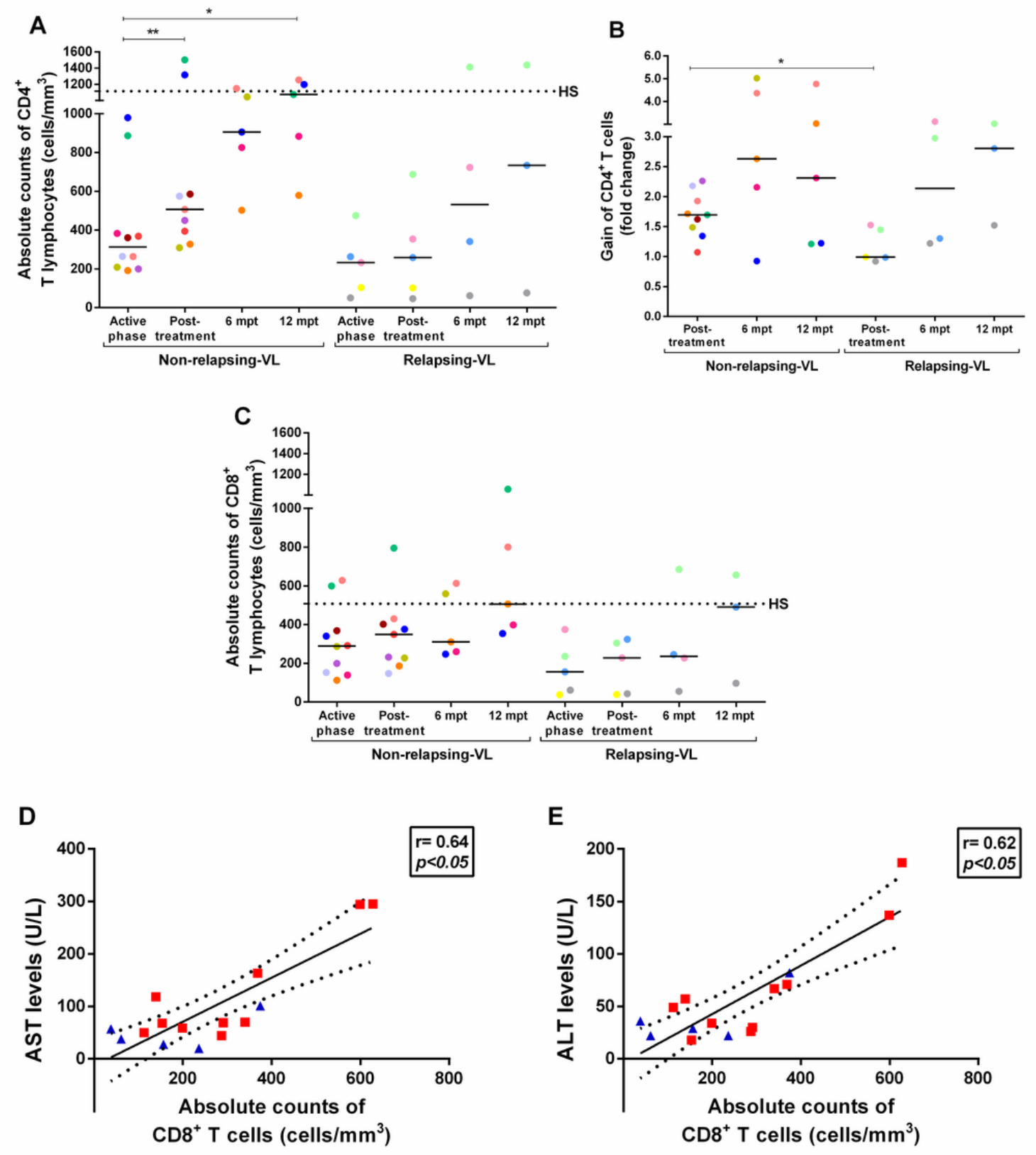

- Non-Relapsing-VL (Active phase) \ Relapsing-VL (Active phase)

Figure 2

Evaluation of immune impairment in visceral leishmaniasis $(\mathrm{VL})$ patients throughout clinical follow-up. Absolute counts of CD4+ (A) and CD8+ (C) T lymphocytes of non-relapsing (NR) and relapsing (R) VL patients. Gain of CD4+ T lymphocytes during clinical follow-up in relation to the active phase of VL (B). Positive correlation between the absolute counts of CD8+ T lymphocytes and the aspartate aminotransferase - AST (D) and alanine aminotransferase - ALT (E) levels during the active phase of $\mathrm{VL}$ (Spearman correlation, $r=0.64$ and $r=0.62$, respectively, $p<0.05$ ). Each point represents a VL patient and each color represents the same patient in the different stages of clinical follow-up. The black dashed line represents the median value of healthy subjects (HS). The horizontal bars represent the median values of each group. Post-treatment: Early post-treatment. Mpt: months post-treatment. Asterisks denote significant differences between the phases of clinical follow-up within the R or NR group itself or even between the R and NR group: * $p<0.05$. ${ }^{\star *} p<0.01$. 

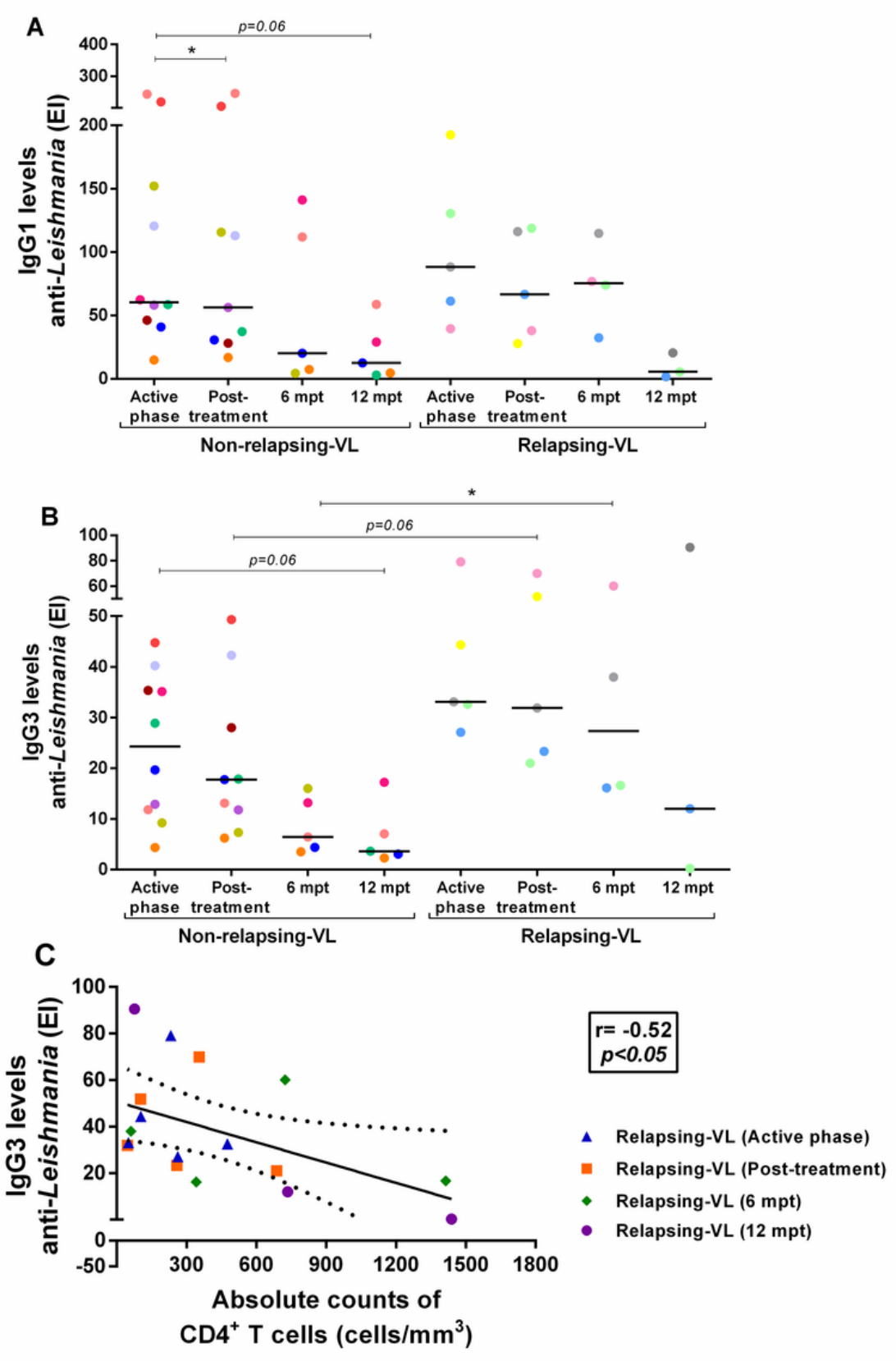

Figure 3

Anti-Leishmania infantum Igs levels in non-relapsing (NR) and relapsing (R) VL patients. IgG1 (A) and IgG3 (B) levels in NR-VL and R-VL patients throughout clinical follow up. Negative correlation between the absolute counts of CD4+ T lymphocytes and levels of anti-L. infantum IgG3 during all the follow-up (C) (Spearman correlation, $p<0.05, r=-0.52$ ). Posttreatment: Early post-treatment. Mpt: months post-treatment. Each point represents a VL patient and each color represents the same patient in the different stages of clinical follow-up. The horizontal bars represent the median values of each group. Asterisks denote statistically significant differences between the phases of clinical follow-up within the R or NR group itself or even between the R and NR group: ${ }^{*} p<0.05$. 

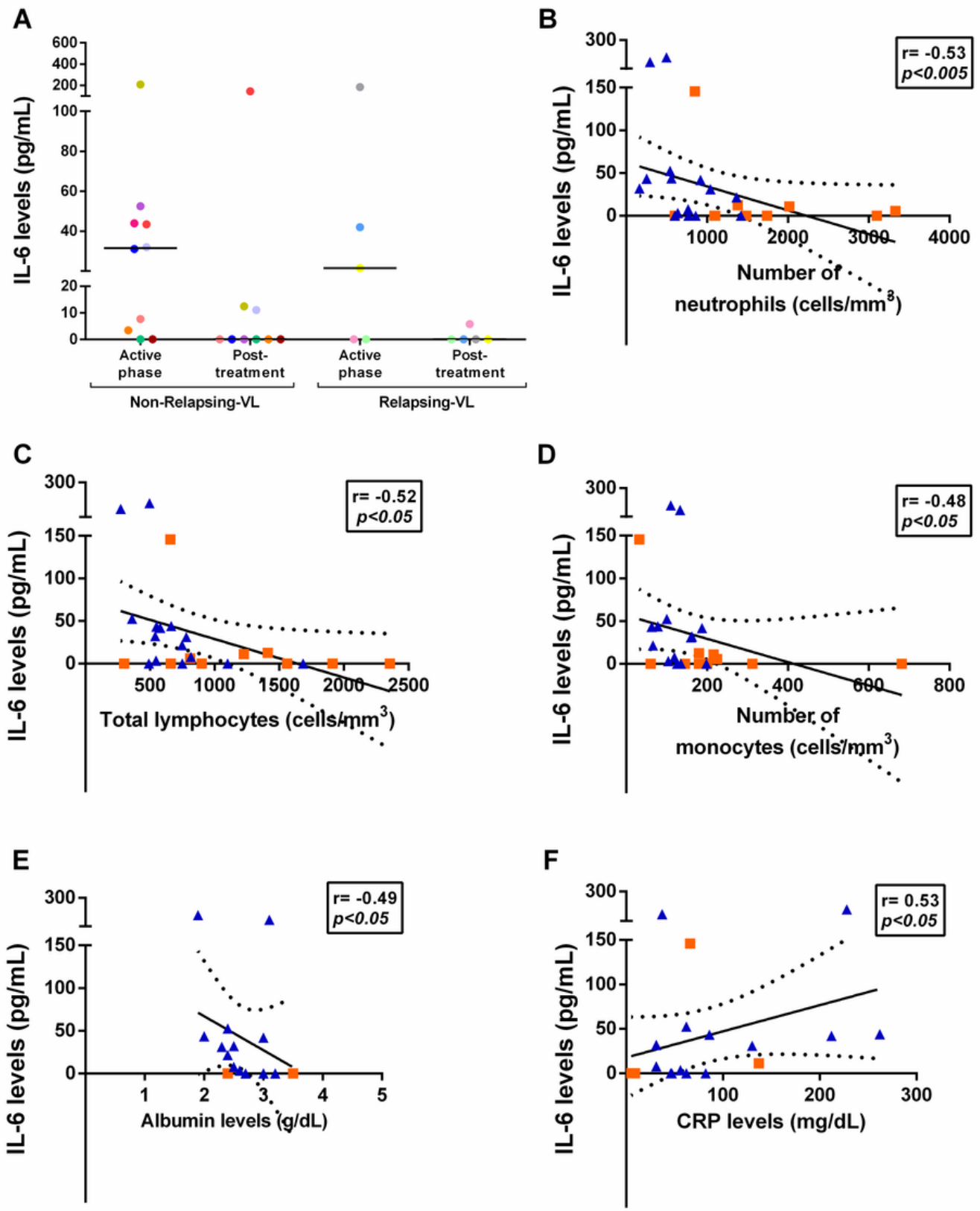

\section{- VL patients (Active phase) = VL patients (Post-treatment)}

Figure 4

Assessment of IL-6 levels and correlation with laboratory parameters in visceral leishmaniasis (VL) patients. Plasma IL-6 levels in non-relapsing (NR) and relapsing (R) VL patients throughout clinical follow-up (A). Negative correlation between the IL- 6 levels during VL active phase and early post-treatment and the neutrophil counts $(B$, Spearman correlation, $r=$ $-0.53 ; p<0,05)$, lymphocyte counts $(C, r=-0.52, p<0.05)$, monocyte counts $(D, r=-0.48, p<.05)$ and albumin levels $(E, r=$ $-0.49, \mathrm{p}<0.05)$. Positive correlation between the IL-6 levels at active phase and early post-treatment and C-reactive protein $(\mathrm{CRP})$ levels $(\mathrm{F}, \mathrm{r}=0.53, \mathrm{p}<0.05)$. Post-treatment: Early post-treatment. Each point represents a VL patient and each color represents the same patient in the different stages of clinical follow-up. The horizontal bars represent the median values of each group

\section{Supplementary Files}


This is a list of supplementary files associated with this preprint. Click to download.

- KuschniretalSupplementaryTable.doc 